\title{
PENGGUNAAN MODEL PEMBELAJARAN KUANTUM SEBAGAI UPAYA UNTUK MENINGKATKAN PRESTASI BELAJAR PKn SISWA KELAS VI
}

\author{
Ni Wayan Setiasih
}

SD Negeri 2 Kukuh Kerambitan

e-mail: niwayansetiasih123@gmail.com.

\begin{abstract}
Abstrak
Perolehan data awal sebagai hasil observasi yang dilakukan ditemukan kenyataan bahwa prestasi belajar PKn siswa kelas VI di semester I tahun pelajaran 2017/2018 baru mencapai nilai ratarata 59,23. Hasil tersebut masih sangat jauh dari ketetapan standar minimal pencapaian mutu pendidikan dengan KKM 75 yang ditetapkan di SD Negeri 2 Kukuh Kerambitan. Tujuan dilakukan penelitian tindakan kelas ini adalah untuk meningkatkan prestasi belajar PKn siswa kelas VI tahun pelajaran 2017/2018 setelah implementasi model pembelajaran Kuantum dalam proses pembelajaran. Penelitian tindakan kelas ini melibatkan 13 subjek penelitian yang dilakukan dalam dua siklus melalui tahapan-tahapan perencanaan, pelaksanaan, observasi/pengamatan, dan refleksi. Tes prestasi belajar merupakan alat yang digunakan dalam mengumpulkan data hasil penelitian yang selanjutnya dianalisis menggunakan analisis deskriptif. Hasil yang diperoleh dari penelitian ini menunjukkan adanya peningkatan kemampuan peserta didik mengikuti proses pembelajaran dari rata-rata awal 59,23 meningkat menjadi 73,54 pada siklus I dan meningkat menjadi 81,31 pada siklus II dengan ketuntasan belajar kegiatan awal $62 \%$ pada siklus I meningkat menjadi $69 \%$ dan pada siklus II meningkat menjadi $92 \%$. Simpulan yang dapat diambil dari hasil tersebut adalah penggunaan model pembelajaran Kuantum sebagai upaya dapat meningkatkan prestasi belajar PKn pada siswa kelas VII SD Negeri 2 Kukuh Kerambitan Tahun Pelajaran 2017/2018.
\end{abstract}

Kata kunci: model pembelajaran kuantum, prestasi belajar PKn.

\begin{abstract}
The initial data acquisition as a result of observations found was found in the PKn learning achievement of Grade VI students in the first semester of the 2017/2018 academic year only reaching an average value of 59.23. This result is still very far from the minimum standard of educational qualifications with KKM 75 set in SD Negeri 2 Kukuh Kerambitan. The purpose of this class action research is to improve the PKn learning achievement of students of class VI in the academic year 2017/2018 after implementing the Quantum learning model in the learning process. This class action research involved 13 research subjects conducted in two cycles through the stages of planning, implementation, observation / observation, and reflection. Learning achievement test is a tool used in the collection of research data which is then analyzed using descriptive analysis. Results obtained from this study The following is an increase in the number of participants participating in the learning process from an initial average of 59.23 increasing to 73.54 in the first cycle and increasing to 81.31 in the second cycle with an initial project learning completion of 62\% in the cycle I increased to $69 \%$ and in the second cycle increased to 92\%. The conclusion that can be drawn from these results is the Quantum learning model that can be drawn from the improvement of Civics learning in VII grade students of SD Negeri 2 Kukuh Kerambitan in the Academic Year 2017/2018.
\end{abstract}

Keywords : quantum learning model, Civics learning achievement. 


\section{Pendahuluan}

Dunia pendidikan selalu mendapatkan sorotan yang sangat tajam berkaitan dengan tuntutan untuk menghasilkan sumber daya manusia yang berkualitas yang mampu menghadapi perkembangan ilmu pengetahuan dan teknologi (IPTEK), sehingga dapat mengikuti perkembangan kemajuan zaman di segala bidang (Degeng, 2001). Berbicara tentang sumber daya manusia (SDM) yang berkualitas, pendidikan memegang peranan amat penting. Oleh karena itu, pembangunan pada bidang pendidikan harus terus dikembangkan ke arah peningkatan mutu pendidikan termasuk mutu pendidikan PKn.

Setelah memaparkan semua harapan yang mesti dipenuhi. Sebagai guru, serta memahami kendala-kendala yang diharapi dapat diketahui hal-hal yang perlu dalam upaya meningkatkan keilmuan dimana sebagai seorang guru harus mengetahui metode-metode ajar; harus menguasai model-model pembelajaran; penguasaan teori-teori belajar; penguasaan teknik-teknik tertentu; pemahaman mengenai peran, fungsi serta kegunaan mata pelajarannya. Apabila betul-betul guru menguasai dan menerapkan tentang hal-hal tersebut dapat diyakini bahwa prestasi belajar siswa pada mata pelajaran PKn tidak akan rendah. Namun kenyataannya, perolehan data awal sebagai hasil observasi yang dilakukan ditemukan kenyataan bahwa prestasi belajar siswa kelas PKn di semester I tahun Pelajaran $2017 / 2018$ baru mencapai nilai 59,23. Hasil tersebut masih sangat jauh dari ketetapan standar minimal pencapaian mutu pendidikan dengan KKM 75 yang ditetapkan di SD Negeri 2 Kukuh Kerambitan.

Pembelajaran dengan menerapkan model pembelajaran Kuantum merupakan salah satu model, strategi, dan pendekatan pembelajaran khususnya menyangkut keterampilan guru dalam merancang, mengembangkan, dan mengelola sistem pembelajaran sehingga guru mampu menciptakan suasana pembelajaran yang efektif dan menggairahkan. Mengkaji dan memahami semua penjelasan tersebut, model pembelajaran Kuantum diupayakan dalam pembelajaran sebagai solusi dalam mengatasi masalah rendahnya prestasi belajar siswa kelasVI B semester I di SD Negeri 2 Kukuh Kerambitan.

Gagne (dalam Dimyati, 2009:10-12) "belajar merupakan kegiatan yang kompleks dimana hasil belajar merupakan kapabilitas". Dimyati dan Moedjiono (2000:4) menyatakan bahwa "prestasi belajar merupakan hasil dari suatu interaksi tindak mengajar atau tindak belajar", setelah belajar orang memiliki keterampilan, pengetahuan, sikap dan nilai. Timbulnya kapabilitas tersebut melalui stimulasi yang berasal dari lingkungan dan proses kognitif yang dilakukan oleh pebelajar.

Slameto (2003: 54-70) bahwa faktor-faktor yang mempengaruhi belajar banyak jenisnya, tetapi dapat digolongkan menjadi dua golongan saja, yaitu faktor intern dan faktor ekstem. Faktor intern diklasifikasi menjadi tiga faktor yaitu: faktor jasmaniah, faktor psikologis dan faktor kelelahan.

Cara berpikir yang diterapkan dalam penelitian ini adalah Kuantum merupakan model pembelajaran yang ampuh dalam meningkatkan prestasi siswa, dalam melaksanakannya guru harus betul-betul aktif, betul-betul membuat persiapan yang matang dan memerlukan pelatihan yang sangat baik. Dengan demikian, model pembelajaran kuamtum akan dapat meningkatkan prestasi belajar siswa, karena dengan pemberian hadiah siswa akan termotivasi untuk memantapkan pemahaman siswa terhadap materi pembelajaran yang telah dipelajarinya sebelum siswa mengikuti tes individual. Dengan meningkatnya motivasi belajar siswa maka prestasi belajar siswa akan meningkat. Bertitik tolak dari kerangka berpikir demikian, maka dapat dinyatakan bahwa dengan penerapan model pembelajaran Kuantum secara efektif akan dapat meningkatkan prestasi belajar siswa dalam mata pelajaran Pkn kelas VI Semester I di SD Negeri 2 Kukuh Kerambitan tahun pelajaran 2017/2018. 


\section{Metode}

Tempat yang digunakan penelitian tindakan kelas ini di SD Negeri 2 Kukuh Kerambitan tepatnya berada di Banjar Kukuh Kelod-Desa Kukuh-Kecamatan Kerambitan-Kabupaten Tabanan karena rendahnya prestasi belajar siswa. Selain itu, mengingat situasi sekolah yang sejuk dan rindang karena banyak pohon tumbuh di halaman sekolah, guru-guru beserta staf pegawai sangat membantu dan mendukung pelaksanaan penelitian ini.

Dalam penelitian tindakan kelas (PTK) ini mengacu pada teori yang dikemukakan Stephen Kemmis dan Robin McTaggrat (dalam Agung, 2005:91). Dalam model PTK ini ada 4 tahapan yaitu: perencanaan, pelaksanaan, observasi dan refleksi. Pelaksanaan penelitian dapat digambarkan dalam model seperti gambar berikut:

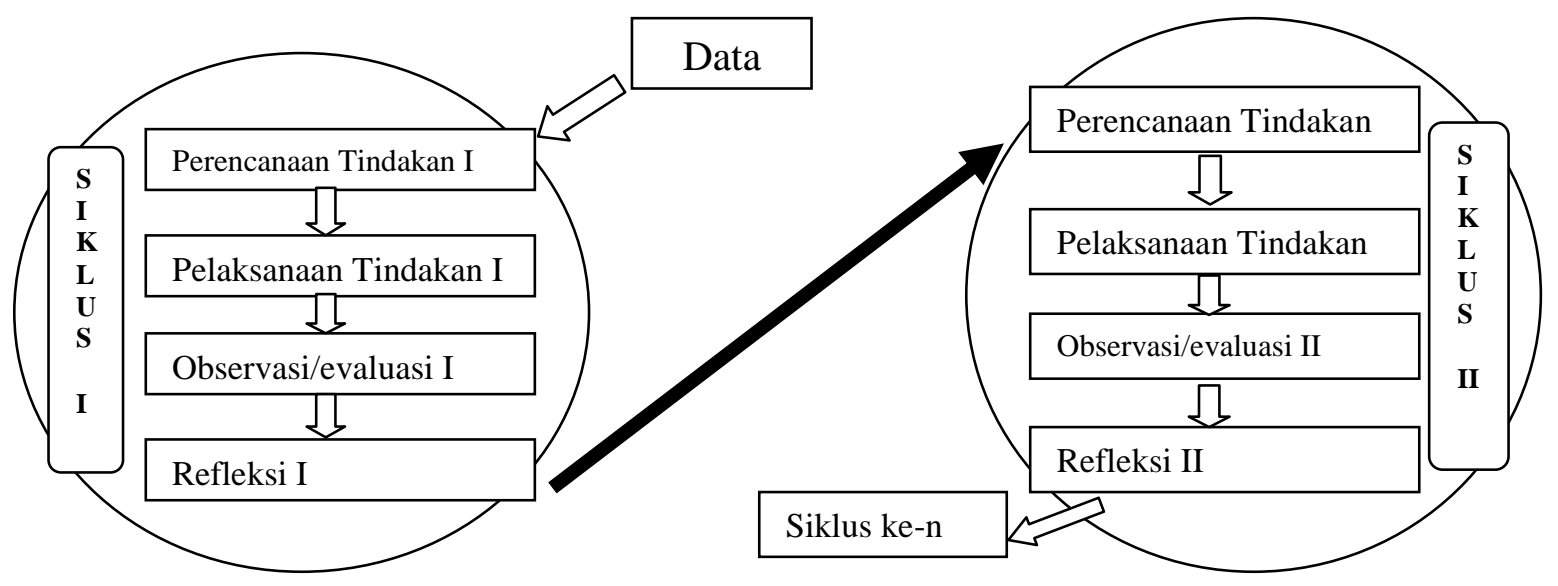

Gambar 1. Model Penelitian Tindakan Kelas Stephen Kemmis dan Robin McTaggart (dimodifikasi dari Sukardi, 2008:214).

Subjek dari penelitian ini adalah siswa kelas VI yang belajar pada Semester I Tahun Pelajaran 2017/2018 di SD Negeri 2 Kukuh Kerambitan. Semua siswa kelas VI berjumlah 13 orang siswa.

Dapat disampaikan bahwa objek penelitian ini adalah peningkatan prestasi belajar PKn siswa kelas VI SD Negeri 2 Kukuh Kerambitan Semester I tahun pelajaran 2017/2018 yang terpenting sehingga yang menjadi fokus dalam penentuan objek penelitian mengarah pada peningkatan prestasi belajar. Dalam melaksanakan Penelitian Tindakan Kelas ini, dilakukan sesuai langkah yang telah ditentukan dan dilakukan bersiklus. Siklus yang dilakukan direncanakan akan berlangsung sebanyak 2 kali. Untuk penelitian ini, Untuk penelitian ini, ditentukan akan berlangsung dari bulan Juli 2017 sampai bulan Nopember 2017.

Data dalam penelitian ini dianalisis dengan analisis deskriptif kuantitatif, berupa ratarata dan presentase, serta pembandingan dengan indikator keberhasilan penelitian, juga dilakukan penyajian data dengan menyusun tabel dan grafik. Yang menjadi tingkat keberhasilan target pencapaian untuk menandakan akhir penelitian yaitu apabila siswa mencapai nilai rata-rata 75 dan dengan presentase ketuntasan belajar minimal mencapai $85 \%$.

\section{Hasil dan Pembahasan}

\section{Deskripsi Awal}

Pada kegiatan awal diperoleh data yaitu, nilai rata-rata hanya mencapai 59,23 sedangkan ketuntasan belajar baru mencapai 8 orang siswa (62\%) dari 13 orang siswa di kelas VI pada semester I tahun pelajaran 2017/2018 memperoleh nilai diatas KKM. Ada 5 orang (38\%) yang memperoleh nilai dibawah rata-rata KKM. 


\section{Deskripsi Siklus I}

Dapat disampaikan analisis pada Siklus I ini, penilaian terhadap kemampuan anak menerpa ilmu pada mata pelajaran PKn adalah, dari 13 siswa yang diteliti, 9 (69\%) siswa memperoleh penilaian di atas KKM artinya mereka sudah mampu menerpa ilmu sesuai harapan. $4(31 \%)$ siswa memperoleh penilaian di bawah KKM artinya kemampuan mereka masih rendah. Dari analisis kualitatif sudah disampaikan secara singkat, selanjutnya diberikan analisis kuantitatifnya menggunakan data yang diperoleh adalah dalam bentuk angka sebagai berikut :

a) Rata-rata (mean) dihitung dengan: $\frac{\text { Jumlah nillai }}{\text { Jumlah siswa }}=\frac{956}{13}=73,54$

b) Median (titik tengahnya yang diperoleh dari data siklus I dengan menggunakan cara tersebut adalah: 75

c) Modus (angka yang paling banyak/paling seringmuncul) setelahdiasccending/diurut. Angkatersebutadalah: 75

d) Untuk persiapan penyajian dalam bentuk grafik maka hal-hal berikut dihitung terlebih dahulu.

$$
\begin{aligned}
& \text { Banyak kelas } \begin{aligned}
(\mathrm{K}) & =1+3,3 \times \log (\mathrm{N}) \\
& =1+3,3 \times \log 13 \\
& =1+3,3 \times 1,11 \\
& =1+3,68=5
\end{aligned} \\
& \text { Rentang kelas } \begin{aligned}
(\mathrm{r}) & =\text { skor maksimum - skor minimum } \\
& =80-56=24
\end{aligned} \\
& \text { Panjang kelas interval }(\mathrm{i})=\frac{F}{K}=5
\end{aligned}
$$

Tabel 1. Data Kelas Interval Siklus I

\begin{tabular}{ccccc}
\hline No & Interval & Nilai Tengah & Frekuensi Absolut & Frekuensi Relatif \\
\hline 1 & $56-60$ & 58 & 1 & $8 \%$ \\
2 & $61-65$ & 63 & 1 & $8 \%$ \\
3 & $66-70$ & 68 & 2 & $15 \%$ \\
4 & $71-75$ & 73 & 5 & $38 \%$ \\
5 & $76-80$ & 78 & 4 & $31 \%$ \\
\hline TOTAL & & & 13 & $100 \%$ \\
\hline
\end{tabular}

\section{Deskripsi Siklus II}

Hasil yang diperoleh dengan pemberian tes prestasi belajar dapat dijelaskan: dari 13 siswa yang diteliti sudah ada 12 siswa (92\%) mendapat nilai rata-rata KKM dan melebihi KKM. Interpretasi yang muncul dari data tersebut adalah bahwa mereka sudah sangat mampu melakukan apa yang disuruh. Sedangkan 1 orang $(8 \%)$ anak yang mendapat nilai dibawah KKM yang artinya tersebut belum mampu melakukan apa yang disuruh. Analisis ini menunjukkan bahwa lebih dari setengah anak sudah mampu meningkatkan prestasi belajarnya. Dengan semua hasil tersebut dapat dideskripsikan bahwa indikator keberhasilan penelitian yang diharapkan sudah terpenuhi. Dari analisis kualitatif sudah disampaikan secara singkat, selanjutnya diberikan analisis kuantitatifnya menggunakan data yang diperoleh adalah dalam bentuk angka sebagai berikut :

a) Rata-rata (mean) dihitung dengan: $\frac{\text { Jumlah nilai }}{\text { Jumlah siswa }}=\frac{1057}{13}=81,31$

b) Median (titik tengahnya) yang diperoleh dari data siklus I dengan menggunakan cara tersebut adalah: 85

c) Modus (angka yang paling banyak/paling seringmuncul) setelahdiasccending/diurut. Angkatersebutadalah: 85 
d) Untuk persiapan penyajian dalam bentuk grafik maka hal-hal berikut dihitung terlebih dahulu.

Banyak kelas $(\mathrm{K})=1+3,3 \times \log (\mathrm{N})$

$$
\begin{aligned}
& =1+3,3 \times \log 13 \\
& =1+3,3 \times 1,11 \\
& =1+3,68=5
\end{aligned}
$$

Rentang kelas $(r)=$ skor maksimum - skor minimum

$$
=89-65=24
$$

Panjang kelas interval $(\mathrm{i})=\frac{r}{K}=5$

Tabel 2. Data Kelas Interval Siklus II

\begin{tabular}{ccccc}
\hline No & Interval & Nilai Tengah & Frekuensi Absolut & Frekuensi Relatif \\
\hline 1 & $65-69$ & 67 & 1 & $8 \%$ \\
2 & $70-74$ & 72 & 0 & $0 \%$ \\
3 & $75-79$ & 77 & 3 & $23 \%$ \\
4 & $80-84$ & 82 & 2 & $15 \%$ \\
5 & $85-89$ & 87 & 7 & $54 \%$ \\
\hline TOTAL & & & 13 & $100 \%$ \\
\hline
\end{tabular}

Berdasarkan hasil penelitian di atas, setelah diterapkannya model pembelajaran Kuantum pada pembelajaran PKn kelas VI di SD Negeri 2 Kukuh Kerambitan meningkatkan aktivitas yang mengarah pada peningkatan prestasi belajar siswa. Berdasarkan semua tindakan yang telah dilakukan, diperoleh kemajuan-kemajuan yang sesuai harapan. Dalam pelaksanaan proses belajar mengajar model pembelajaran Kuantum mampu menumbuhkan minat siswa untuk belajarlebih giat namun karena pada awalnya model ini belum digunakan sehingga hasil awal baru mencapai 59,23 pada siklus I dapat ditingkatkan menjadi 73,54 dan pada siklus II dapat ditingkatkan menjadi 81,31 setelah penggunaan model pembelajaran Kuantum dalam proses belajar mengajar. Model pembelajaran Kuantum mampu membantu siswa menggunakan ingatan serta transfer ilmu yang lebih sesuai harapan karena kebenaran teori yang ada.

Berdasarkan uraian diatas, penelitian ini secara umum telah mampu menjawab rumusan masalah. Hal ini berarti bahwa penelitian ini telah mampu memecahkan permasalahan rendahnya prestasi belajar PKn Semester I SD Negeri 2 Kukuh Kerambitan tahun pelajaran 2017/2018. Pada akhir penelitian semua kriteria keberhasilan penelitian telah terpenuhi. Dengan kata lain, penelitian tindakan kelas yang dilakukan telah berhasil.

\section{Simpulan dan Saran}

\section{Simpulan}

Kesimpulan dari penelitian yang dilakukan adalah sebagai bahwa model pembelajaran Kuantum dapat meningkatkan prestasi belajar PKn Siswa Dengan pencapaian tujuan pembelajaran membuktikan peningkatan prestasi belajar, oleh karena itu dapat ditarik simpulan bahwa implementasi model pembelajaran Kuantum dapat meningkatkan prestasi belajar PKn pada siswa kelas VI SD Negeri 2 Kukuh KerambitanTahun Pelajaran 2017/2018.

\section{Saran}

Mengacu kepada hasil temuan penelitian ini, dapat dikemukakan beberapa saran sebagai berikut.

1. Bagi Siswa 
Peserta didik hendaknya dapat berperan aktif dengan menyampaikan ide atau pemikiran pada proses pembelajaran, sehingga proses pembelajaran dapat berjalan dengan lancar sehingga memperoleh prestasi belajar yang optimal.

2. Bagi Guru

Untuk meningkatkan prestasi belajar PKn diharapkan menggunakan model pembelajaran Kuantum.

3. Bagi Sekolah

Bagi sekolah diharapkan penelitian ini dapat dijadikan sebagai pedoman dalam pelaksanaan pembelajaran disekolah tersebut khususnya pada pembelajaran PKn untuk meningkatkan kualitas pembelajaran PKn itu sendiri.

4. Bagi Peneliti lain

Bagi peneliti lain diharapkan lebih mempersiapkan diri dalam proses pengambilan dan pengumpulan dan segala sesuatunya sehingga penelitian dapat dilaksanakan dengan lebih baik. Peneliti selanjutnya diharapkan ditunjang pula dengan wawancara dengan sumber yang kompeten dalam kajian sarana prasarana pendidikan dan efektivitas proses pembelajaran.

\section{Daftar Pustaka}

Agung, Anak Agung Gede. 2005. Metodologi Penelitian Pendidikan. Fakultas IImu Pendidikan Institut Keguruan dan Keilmuan Negeri Singaraja.

Arikunto, Suharsimi; Suhardjono; Supardi. 2006. Penelitian Tindakan Kelas. Jakarta: PT Bumi Aksara.

DePorter, Bobbi dkk. 2000. Quantum Teaching : Mempraktekkan Quantum Learning di Ruang-Ruang Kelas. Bandung : Kaifa.

-, 2004. Quantum Learning: Membiaasakan Belajar Nyaman \& Menyenangkan. Bandung: PT.

Dimyati. 2009. Belajar dan Pembelajaran. Jakarta: Depdikbud.

Dimyati dan Mudjiono. 2000. Belajar dan Pembelajaran. Jakarta: Dirjen Dikti.

Nurkancana, Sunartana. 2001. Evaluasi Hasil Belajar. Surabaya: Usaha Nasional.

Slamet, PH. 2003. MBS, Life Skill, KBK, CTL dan Saling Keterkaitannya.Makalah yang Disampaikan pada Semiloka DBEP di NTB dan Bali.

Slameto. 2003. Belajar dan Faktor-Faktor yang Mempengaruhinya. Jakarta: Rineka Cipta.

Sukmadinata, Nana. 2005. Landasan Psikologi Proses Pendidikan. Bandung: PT Rosda Karya.

Tim Penyusun, 2005, Kamus Besar Bahasa Indonesia, Jakarta: Balai Pustaka. 